\title{
Intuitive Law in the Light of Independent Ethics
}

\author{
Matgorzata Obrycka \\ Pomeranian University \\ in Słupsk, Poland \\ e-mail: obryckamalgorzata@gmail.com
}

\begin{abstract}
:
The conception of the paper is connected with bringing forward the reflection of Leon Petrażycki on intuitive law. For this purpose I analyze the genesis and dynamics of this phenomenon on the cultural-historical level, as well as with reference to issues belonging to the scope of positive law. In addition, I broaden the research field with the range of problems touching on intuitionism, morality, and also independent ethics of Janusz Kotarbinski. The starting point of the methodological optics I assume is constituted by the multi-aspectual transformations surrounding us in the sphere of axiology. Hence, if the pedagogical aspects are taken into account, it seems to me justified to undertake some actions in order to search for the logically consistent, sensible and universal solutions, which can become an ethical guide-post for the contemporary human being.

Keywords: independent ethics, intuitionism, morality, intuitive law, ethical education.
\end{abstract}

\section{Introduction}

The modern social-cultural conditions have transfigured the everyday ways of our functioning. The earlier narratives seem to by non-adequate to the today's needs. The concrete and coherent goals of proceedings, which were offered to us by tradition, become dispersed and changed into the ones that are less clear, sometimes internally contradictory and indifferent. In the context of these determinants, various anxieties and disquietudes have appeared. On the other hand, new possibilities and alternatives are propitious to the self-reliant determination of the goals and values that are closest to us. The cultural capital that we develop during the whole life is far from playing a minor role on this level. There are contained in it - not always, unfortunately - reflectiveness, contextuality, and dialogicality. It is these features that influence the way we perceive norms and principles of behavior. Frequently, the choice of a definite way of acting is unconscious or poorly embedded in the context of diversified aspects making up the whole issue. It's worthwhile then to dedicate a moment of time in order to gain - in such an important sphere of life as the ethicality more self-awareness and understanding of the complexity of that which determines the problems and dilemmas troubling us, manifesting themselves in both personal and community life. 
Keeping what was said above in mind, I made the purpose of the reflections undertaken here to bring forward the range of issues touching on intuitive law, elaborated by Leon Petrażycki. In the text I propose the fundamental assumptions delimiting intuitive law from positive one. I broaden the question of intuition itself by performing the analysis of the main assumptions of the philosophical current that is the empirico-emotionalist intuitionism. Hence I situated the undertaken reflections in the context of the questions within the scope of the status of the independent ethics formulated by Tadeusz Kotarbiński. The common - to the both savants - categories of conscience and intuition are revealed on this cognitive level. One more yet fundamental question joins the research approaches discussed by me, namely, the fact that both Petrażycki and Kotarbiński attached in their investigations great significance to the range of problems concerning the human attitude to the rest of the living beings.

The essence of the so-planned actions is getting to know and determining the role played by understanding and percepting the rules of law in the perspective of individual feelings and desires. The crucial question is, moreover, the ethical education we have contact with during our lives both with reference to the institiutional influences and to the informal ones. I refer the above questions to the proces of the formation of the moral identity assumed by the contemporary human being [24]. Therefore, the proceeding of this type aims at the recognition of the interdependence occuring between law and morality. The ethical and pedagogical aspects of law, as well the interdependences between motivational and pedagogical influences of law, are for me crucial.

\section{Intuitive Law in the Context of the Social Adaptation}

Leon Petrażycki was an unusually comprehensive man. ${ }^{1} \mathrm{He}$ was interested in many issues within the range of social-humanistic sciences. Philosophy and its subdisciplines, such as ethics and logic, were close to him. Apart from questions of law, the thinker was curious about theories and conceptions disclosed on the ground of sociology and psychology. Kotarbiński himself highly praised the scientific achievements of Petrażycki in this way:

at last the time has come to understand that in the works of Leon Petrażycki rare treasures of the oryginal genuitity are contained, so much precious that it would by worthwile to undertake the Polish publication of his works, if not of all of them, then at least of the main, guiding, the most outstanding ones [8, pp. 484].

Petrażycki payed the particular attention in his works to the complexity of the processes that constitute the mutual relationships among morality, esthetics and the human psyche. We won't deny that these areas, together with other contexts, incessantly transform us, as well as help us in the adaptation to the social functioning. Petrażycki notices on this plane the specific fundament for the genesis, development and dynamics of legal arrangements. As we get to know from the writings of the thinker, legal regulations are also subjected to these multiplanar processes of the unconscious adjustment [19, pp. 139-152]. The adequacy of law to the human needs is associated by the philosopher with the question of the universal good. Petrażycki notices in this perspective the factors, conscious to us, as well as the unconscious ones, which consequently lead to the transformation of legal norms. The scientist writes about a particular form of the human communion on the plane of emotional-intellectual associations. What is important here are cognitive dissonances, and so what is offered to us by the inherited predispositions - together with what we acquire through the everyday experience [3, p. 67].

Petrażycki effectuates the division of laws into intuitive and positive ones [19, pp. 267-276]. The former of them are characterized, first of all, by the fact that they don't contain among their arrangements any imaginations of normative facts. It is only the question of self-awareness, accompanying the choice of the appropriate way of behavior, without referring to - differently conceived of - authorities, that is important on this level. The upbringing that we've received, our 
education, the adherence to formal and informal groups, or the job we do are here of equal importance. Our character traits and personal acquaintances, friendships and relationships are also equally essential. The accordance of intuitive experiences is secured by the similar, or even the same conditions of life. ${ }^{2}$ In spite of these determinants, Petrażycki underlines with all his might that intuitive law has an individual character, because of which it is changeable and varied. In this context an important condition of intuitive law is revealed to us, as it is independent on any statutory provisions.

The above conclusions concerning intuitive law were elaborated with relation to positive law. That which connects the two terms regards the factuality itself of the content because it may be unreasonable and harmful on the both sides. Whereas the element differing these questions is the assumption, according to which positive law is built on the ground of the perception of external facts. Hence there's no talking here about the free-and-easy adjusting norms to the individual context. The law of this kind delivers norms that are uniformed for everyone. Besides, in the opinion of the conception's author, this type of law embraces these spheres of life which don't manifest themselves in people's consciousness as forms of receiving and giving the good or the evil. As far as this question is concerned, the author has in mind the formation of the official international relations and the functioning of the national jurisdiction and administration. Therefore, thanks to the establishments elaborated in the framework of positive law, the normal social life and the lasting social order may be developed [3, pp. 68-78].

The philosopher specifies the above questions in the following way:

while being individually heterogenous, as far as the content is concerned, intuitive law differs from positive law also in that its decisions are adjusted in a free way to the concrete, individual circumstances of a given case, a given arrangement of the living relations. They are not constrained - as it takes place in the domaine of positive law by any pre-established pattern of the relevant legal rules, the introduced customs, etc., which contain regulations prescribed for particular cases of general categories, don't take into account the multitude of individual features in the specific circumstances of life, can't foresee them and adjust themselves to them [19, p. 270].

It's worthwhile to accentuate that Petrażycki called 'moral duties' only those which are purely and simply free with reference to other people, they are then duties not implicating any claim.

The author conducts his deliberations taking into consideration the historical aspect. He remarks in that matter that in the light of the conditions having their source in the past positive law may undergo the process of the slowdown of its development. ${ }^{3}$ This state of affairs is influenced by the situation regarding not keeping up with the cultural-technical transformations. The historical context manifests itself also on the horizon of changes introduced too violenly, which haven't as yet found any understanding in the mentality of the particular social groups. ${ }^{4}$ In turn, "intuitive law develops regularly, slowly, it doesn't undergo any fixation, petrification and it is not dependent on anyone's sef-willedness" [19, p. 272]. However, this characteristic - as the author himself remarks - doesn't guarantee the choice of better decisions. This is influenced, first of all, by the conditions of development, of education and the cultural level, and these are often the processes unproperly or pathologically determined. In such situations the space is produced for the application of positive law.

The philosopher remarks that we find the essential differences between intuitive and positive aspects of ethics - in the sense of the preponderance of positive elements - on the ground of the domain of morality. The author expresses his position in the following way:

if the content of the positive Christian or Buddhist morality would be compared with the past or present intuitive morality of Christians or Buddhist, one could become 
convinced that this intuitive morality is in large measure something far less noble, and even something pitiful as compared with the positive morality [19, p. 273].

As regards this question, the author adds that for the right understanding of the Gospels it must be made conscious that they are unilaterally-imperative teachings, and hence "(...) if any social-legal claims, etc., are derived from the teachings of the Gospels at present - it is a misunderstanding and a distortion of their meaning" [20, p. 86].

We find the similar reflections in the field of the recognition of these spheres of life, which stay outside of the sphere of positive-legal norm-setting. The author has in mind also such categories as family, friendship or love. The complexity as well as delicacy of these relations cause the application of the individual intuitive law, and so what is all the talk here about are the indications of one's conscience. Petrażycki remarks that it is the context of causing or receiving the good or the evil that is directly connected with the essence of intuitive law.

We find also in the works of the scholar the analysis of the endangerments which the discussed forms of law carry with themselves. One of the main defects is revealed by the question of the social good and it concerns the substantial content contained in the intuitive law's transmition. The great part is obviously played in this dimension by the education and Petrażycki pays his attention repeatedly to this issue. In the lifetime of the thinker, as well as today, the moral level, the level of customs, and the pedagogical culture of particular social groups were and are very differentiated. This state of afairs has its influence on that which we define as intuitive.

The question itself of motivation is extraordinarily crucial. In the opinion of Petrażycki, the legal motivation exerts a larger influence on the social life, and also it has a greater meaning in it than the moral motivation. The author remarks that the social progress is conditioned by the propagation - in the social psyche - of the association of the imaginations of behavior with the emotions connected with law. Such activity carries with itself benefits for the whole community. According to this understanding, the development of the legal psyche shapes the most fully the character of particular people, as well as the sound interpersonal relationships [7, pp. 22-23].

It has to be added that the lawyer perceived the psyche as an active and authonomic system. ${ }^{5}$ Actions in this conception aren't oriented by hedonistic factors but precisely by emotions revealing themselves, among others, through imaginations of the concrete actions. The scholar underlines the educational aspect of the legal self-awareness. Self-respect and sense of dignity count here.

Keeping in mind the analyses performed by himself, Petrażycki acknowledges the priority of intuitive law over positive law. It is this type of law that has to prevail over the uniformed provisions of civil and criminal law. Apart from this, it has to be the determinant and the stimulator of formulating and transforming themselves of the social-legal conditions. However, making his views more precise, the author underlines in an unequivocal way the need for the existence of the two types of law. The spheres of their influences should complement and permeate each other. Petrażycki remarks, however, that areas left by positive law to the influence of intuitive law should be broadened out regularly with the lapse of time. Moreover, the accordance of contents of the guiding principles with one another should exist between the discussed kinds of law. The fundament of this type ensures the legal order and the appropriate social, political, as well as economical system. In this understanding,

(...) the development of the both species of law, the intuitive law, as well as the positive one, determines, in the general and principal outlines, the impact of the same socialpsychical processes, proceeding according to the same rules, and the partly unlike outcomes of the development, the diverse particular, inessential for the most part, differences regarding contents come into being only in connection with the specific difference between the intellectual compositions of intuitive and positive law [19, p. 277]. 
The reflection of the scholar that it may come to the transfiguration or even the collapse of positive law in the situation of coming into existence of a large divergence between the two forms of law remains not devoid of significance. The concept of the intuitive-legal conscience also appears in the texts of the thinker, and both conscience and intuition are the crucial concepts, on which Tadeusz Kotarbiński builds the notion of independent ethics.

\section{The Category of Intuition in Social Sciences}

This subsection will serve me to situate both the issue of intuitive law and the empiricalemotionalist intuitionism in the broader context of the system of sciences. In order to achieve this I will discuss the concepts of intuition and intuitionism [16, pp. 15-49].

According to the etymology of the word, intuition is joined with the Latin term intuitio, meaning vision, presentiment and immediate understanting. ${ }^{6}$ We notice its manifestation on the various levels of our functioning, first of all, in the emotional and intellectual dimensions. Intuition expresses itself also in the concrete activities, which should let us reach directly a certain being, through defining its fundamental aspects, or make it possible to find a solution of the problem that troubles us [3, p. 7].

Wincenty Okoń presents an interesting interpretation of the discussed term, and he performs this recognition, taking into account its pedagogical-philosophical horizon. In the opinion of the researcher, intuition consists in "[...] the judgements and beliefs directly imposing themselves, not based on the conscious operation with the premises, on the conscious reasoning" [18, p. 156]. What is crucial here is the promotion od the actions performed in favor of shaping the skills of perception, embracing the whole of problematic issues, without the sense of the awareness of the way in which one attains the concrete answer. It is then an unconscious process [26, pp. 225-252].

In this place of the argumentation I will present the main presumptions of the philosophical and empirical current which is intuitionism. The character of this cognition consists in grasping the concrete phenomenon without referring oneself to the reasoning and acting. Among the researchers of the discussed problematics we must enumerate, first of all, Plato, Aristotle, Saint Augustin, Descartes, Lock, Kant, Pascal, Brentano, Wittgenstein, Russell, and also Bergson. On the ground of the Polish elaborations within the range of ethics "[...] R. Ingarden and, in a certain sense, T. Kotarbiński went the way of Brentano and of fenomenologists, whereas Wł. Tatarkiewicz, T. Czeżowski, H. Elzenberg opted for the intuitionism in Moore's edition" [3, p. 49].

Searching for more significations ascribed to intuition, it's worthwile to mention the theological interpretation. On this level intuition "(...) means that a certan reality is immediately given to the act of cognition and in this act" [21, p. 182]. There's no way not to mention the activity of which Max Scheler gave evidence in this matter. This researcher interpreted values objectively, which means that he defined their existence as properties of the world. According to this understanding, it is thanks to intuition that we get to know the values: religious, spiritual, vital, hedonistic or utilitarian. The source and the fundament of intuition are emotions [22], [23].

In the psychological sense intuition is interpreted as an imposing itself on us belief, which we can't justify precisely [6]. Following this track, intuition “(...) originates since it emerges as the outcome of the unconscious transference of the attitudes generated with reference to the similar situations or as the outcome of very weak stimuli" [4, pp. 8]. We get to know - on the ground of the elaborations having its origin in cognitivist psychology - that every processing of information takes place with the help of associations, patterns and images. And this is why cognitivists work out the methodology serving to define the concrete mechanisms of the conscious functioning, as well as of all the unconscious processes.

I want to emphasize that the position of intuitionism was, and still is, repeatedly criticized. The polemics touching on this issue refer to the objections connected with the sense of the lack of historicity, as well as the necessity of preserving the oppositions between that which we regard as factual and that which concerns the emotional sphere [14, pp. 318-319]. The dangers associated 
with the intuitive feeling have been described by essentialists. In their opinion, each thing operates in agreement with its nature and only such its operating leads to the good.

The research analyses performed within the scope of the studies on intuitionism have disclosed a bit different character of intuition. Now it's not at all perceived exclusively through the prism of mysticism and irrationalism. Intuition has become a scientific category. It turns out that our intentions regarding phenomena and objects are the vehicle for very many informations. ${ }^{7}$ The sketched problems are evident in the statement of Anna Drabarek, in whose opinion, "the fact itself that all the positive sciences strive to prove every truth that is proclaimed by them, and so to confirm, to verify, that is, to validate it by experience - is, looking at it from the metascientific perspective, also dictated by intuition. It can be said then that both the basic assumptions of logic and the axioms of other sciences based on them have the intuitive character" [3, p. 29]. Hence, the evidence derived exclusively from the rational and empirical research activities appears as secondary with relation to the initial, intuitional assumptions. These are questions about which it is especially worthwhile to remember while analyzing the educational processes.

\section{The Independent Ethics - Morality and Intuition}

Kotarbinski defines ethics as the worldly wisdom because it constitutes for him 'the totality of advices - obviously striving to be rational, and answering the question how to live' [11, p. 23]. In order to present the complexity of this discipline, the researcher proposes its division. He creates then three subdisciplines of the traditional ethics:

1) praxeology (the science of the efficient action);

2) felicitology (the science of happiness);

3) ethics in the strict sense of the world.

This division leads to further demarcations, which is disclosed by the next statement of the philosopher: "we can distinguish moral and biochemical issues. The former are about how to live honestly, the latter - how to live happily. Only the whole of answers constitutes the personal practical wisdom" [10, p. 463].

Indicating the specified areas of ethical influences, Kotarbiński evokes a very important category, which also appears in the works of Petrażycki, and it is the conscience. For the representant of the Lvov-Warsaw School ethics is the analytical study of the conscience because "taking the conscience as the point of departure, analyzing its fundamental data, one can resolve a moral problem, that is, answer the question what the moral good is, how one should act to deserve the moral respect, and what is the principal norm of demeanor" [2, p. 129]. In this understanding the conscience isn't perceived as an instinct. It isn't also seen as an attribute of the reason. Furthermore, neither is it a feeling. For the ethician it is a definite and specific ability, joining in itself heterogenous aspects of the human functioning. Therefore, these predispositions that enable the conscience to be generated, were acquired in the course of one's history. ${ }^{8}$ Taking into account the propositions of Kotarbiński, we can ask the question about the possibility of coming into existence of a real chance for establishing the ethical system - based on the obvious judgements - the basic property of which is the independence from any religious, philosophical, anthropological, and even political worldview [17, pp. 223-240]. The author refers us back to the voice of the conscience, conditioning the universality of the exemplar of the honest man, called by him a reliable guardian. The savant assumes the thesis, according to which it is the timeless, worthful and noble intentions, springing from our conscience, that can constitute the interpretative fundament of our behavior. The role of intuition becomes visible in this place, indicating us what is good, and what is shameful - something similar happens in Petrażycki's works. ${ }^{9}$

Let's stop for a while by the interpretation of these behaviors and acts. The intentions and motives, defined as good in the moral sense, receive in Kotarbiński's works the name - venerable. The following ones belong to them: good heart, dedication, friendliness, honesty, care for other people and animals, generosity, courage, perseverance in the face of hardships, and internal 
discipline. Evil acts are defined by the ethician as infamous. Here the author means unreliability, unjustice, and cruelty. This is the perspective on which the ethical axioms are built, such as: 'kindness is more supreme than maliciousness, righteousness - than unlawfulness, courage - than cowardliness, self-control - than lack of will, moral dynamism - than apathy' [10, p. 249]. In the light of this interpretation we can try to discuss the universal values, constituting for each of us the orienting points in a concrete problematic situation. ${ }^{10}$ In the opinion of the philosopher, we have the intuitive abilities to detect the concrete values, thanks to which we gain the possibility of in-dept recognizing a complex, problematic situation. Once more the question of intuition, interpreted in the meaning of the heart's obviousness and the moral sense appears in the course of the presentation. In agreement with this mode of argumantating, it is from the conscience that we should derive moral indications, independent from any ideology, religion, and even science. Let's add that the criteria of the good ought to be verified by referring them to the everyday moral experience.

The conscience is both an evaluating judge and an emotion taking the form of the sense of shame. Assuming this interpretation, the desirable legal and cultural state of affairs should be for each of us the conscience disquieted by remorses.

This type of thinking is characterized by empirism and emotionality. According to this conception, there is then the ethical experience in the form of feeling [5, pp. 133-134]. In the perspective thus defined the common moral sense ought to constitute the pattern of behavior worthy of imitation. Responsibility for oneself and for others is important, which should manifest itself through the reverence for such principles as justice, disinterestedness and empathy, expressed in the form of fighting and minimalizing the omnipresent suffering of all the living beings.

\section{Conclusions}

The purpose of my investigations was calling the attention of the readers to the question of the recognition of the status of morality in the broad context of the problematics of shaping the ethicallegal indentity of the contemporary human being. The point of departure for the reflection of this type was for me the analysis of the effects, which the diversified transformations carry with themselves, manifesting themselves among others through the laicization of the Polish society, and what follows from it, taking over of the responsibility for one's actions - no longer on the ground of the religious reflections but precisely of the individual and autonomous perceptions. In this cognitive perspective the attempts to reformulate the goals, methods and measures applied in the process of the ethical education were for me equally important. Morover, the changes in the code interpretation of norms and rules, which in the consequence - we see this on the daily basis contribute to the polarization of standpoints and sometimes even conflicts, ${ }^{11}$ remained for me not devoid of significance. In this place of the presentation it's worth referring to the words of Petrażycki, who postulates that:

entrusting the care for the further achievements in the domain of the progress of law to the legislator and his future specialist-counsellor - the science of the politique of law, one has to advocate for the impartial control of - and the help in - the efficient and unwavering realization of everything that has already been or will be obtained with the help of the legislative cards, in order to make these legal achievements constitute magna charta not only on the papers; whereas to reach this goal one has not only to preserve but also revere and love the judisprudence - the living voice of the already conquered laws of the man and citizen as well as the law in general [19, p. 330].

I have referred the above assumptions to the research results obtained by the savants chosen by me - Petrażycki and Kotarbiński - and they took into consideration, first of all, the elementary truths, which had and still have an enormous significance in the social life. The question of the historical overview of the reality, making it possible for us to be able to perceive phenomena in their socio- 
spatio-temporal context, is not without significance for them. The researchers make us aware that by taking into consideration the broader cognitive plane, we will understand why it is worthwhile to subject the traditional instructions, prescriptions or norms to the critical analysis, looking at them from the point of view of their reasonability, consistence and truthfulness [9, p. 11]. It is the critical and reasonable attitude to the generally wide-spread views and evaluations that counts [20, p. 74].

Petrażycki accentuated explicitely the question of developing the strong and vital legal psyche of children, which should manifest itself through instilling into them not only morality but also the law obliging with reference to us ourselves. The question of the respect for the rights of others is also crucial [20, p. 104]. In the savant's opinion:

the outcome of having been brought up «without law» is the lack of a strong ethical attitude and safeguarding against the diverse temptations of the world (...); whereas, as regards particularly the attitude to other people, as well as to oneself, the natural outcome of such having been brought up is a «slavish soul» and simultaneously the lack of consideration for another's dignity, despotism, and vanity. The development of the active legal consciousness is for pedagogy the mater of a great importance also from the standpoint of (economical, etc.) prowess. It imparts to people the indispensible selfconfidence, energy, and entrepreneurship. If the child is brought up in the atmosphere of willfulness, even accompanied by kind-heartedness, if there is not a certain sphere of rights alloted to him/her, certain rights on the immunity of which he/she can certainly count, he/she can't get used to constructing and carrying out any plans with trust [20, p. $105]$.

According to Petrażycki, the concept of the legal consciousness is intertwined with the terms of energy, spirit of enterprise, and bravery in action, both on the individual and the national levels. These are the traits that can be daringly acknowledged as needed and valuable for the educational processes. He transfers the postulates directed at children onto the ground, which he defines as the education of nation, and he regards the legislative politics as the most important means of this education. Kotarbiński himself described the ideal of Petrażycki as the active and universal people's kindness of one to another [8, p. 485].

In this light it can be clearly seen, how important educational tasks are before us. Reinforcing the sense of strength and courage in order for one not to give in to the opinion of the environment - it is one of the more serious educational influences. It is also important to counteract arising of the situation, characterized by the lack of the possibility of transforming the internal structures of the system in case of the appearance of new ethical problems, and this is an extraordinaly difficult task, especially in connection with the institutional setting of teaching. In this context understanding of the basic analyses, elaborated on the field of the intuitive law, which doesn't undergo any fixation or petrification, may turn out unusually helpful. The thinkers in common underline the significance of such characteristics as processualness, changeableness, interpenetration of the opposites. The savants also draw our attention to the category of the conscience, being the reflection of feelings of people professing the leading values, and these are respect for every form of life and counteracting to sufferings. Whereas intuition should complement rational thought in order for the knowledge and the feelings situated in the moral dimension to become in consequence the typical and natural equipment of each of us. It is associated with the question of fighting the intransigence of the worldview and methodological characters. On the basis of these conceptions I advance the thesis - valuable, in my opinion, for pegagogical issues - that we ought to act educationally in such a direction which would let us treat the uniqueness and exceptionality of specific actions, for which we take responsibility individually, as worthy of reflection and even popularization. What we consider to be particularly exceptional and unique in ethical actions, is as important in the process of education as the actions that have already acquired the status of universality. Moral dilemmas and quandaries will incessantly surround us. That is why 
our task is to measure ourselves with that which is ambiguous and doesn't allow to be attributed to any particular ethical or religious doctrine. As far as this question is concerned, it's worth emphasizing, after Petrażycki, that the consciousness of the moral duty and of the legal one, apart from being psychical phenomena, have many more other common features, at least on the level of intellectual and feeling elements.

The authors accentuate the lack of agreement to sanction harmful behaviors, which engender the real suffering and discomfort. The advantage of one entity over another is, according to them, the source of the obligation in relation to the weaker one. The postulates of promoting the responsibility for one's own identificatory group, and for the excluded, people as well as animals, are visible here. Today we realize more and more that our attitude to animals is so much important that the fully scientific exploratory recognition should be conducted within this scope [20, pp. 522], [8, pp. 399-404]. The example of the continuation of the investigations of this type are at the very least the issues elaborated on the ground of the conceptions of ahimsa or posthumanism [25, $\mathrm{p}$. 252], [1], [12], [13].

The presented views, both of Petrażycki and of Kotarbiński, are far from promoting any version of the ethical rigorism. When one starts to follow the profound analysis of the issues elaborated by these two eminent savants, a wise, logical and coherent argumentation appears, transforming itself in the course of the reading into the signpost thanks to which we can work out our own vision of moral-legal reflections.

\section{References}

1. Braidotti, R. Po człowieku, Warszawa: Wydawnictwo PWN, 2014.

2. Choroszy, J. F. Poglądy etyczne Tadeusza Kotarbińskiego, Wrocław: Wydawnictwo Uniwersytetu Wrocławskiego, 1997.

3. Drabarek, A. Intuicja. Poznanie bezpośrednie, Warszawa: Wyższa Szkoła Handlu i Prawa im. Ryszarda Łazarskiego, 2006.

4. Drabarek, A. O poznawaniu dobra moralnego. Różne rozumienie intuicji $w$ etyce polskiej, Lublin: Wydawnictwo Uniwersytetu Marii Curie-Skłodowskiej, 1999.

5. Drabarek, A. Podmiot. Wartościowanie. Działanie, Warszawa: Wydawnictwo Akademii Pedagogiki Specjalnej, 2011.

6. Gigerenzer, G. Intuicja. Inteligencja nieświadomości, Warszawa: Wydawnictwo Prószyński i Ska, 2009.

7. Kojder, A. Wstęp. In L. Petrażycki (ed.), O pobudkach postępowania $i$ o istocie moralności $i$ prawa, Warszawa: Oficyna Naukowa, 2002, pp. 7-48.

8. Kotarbiński, T. Pisma etyczne, Wrocław-Warszawa-Kraków-Gdańsk-Łódź: Zakład Narodowy im. Ossolińskich, 1987.

9. Kotarbiński, T. Przykład indywidualny kształtowania się postawy wolnomyślicielskiej. In K. Sokół (ed.), Religia $i$ ja: Tadeusz Kotarbiński, Leopold Infeld, Bertrand Russell, Warszawa: Wydawnictwo Książka i Wiedza, 1962.

10. Kotarbiński, T. Wybór pism, t. 2: Myśli o myśleniu, Warszawa: Wydawnictwo PWN, 1958.

11. Kotarbiński, T. Żyć zacnie, Warszawa: Wydawnictwo Nasza Księgarnia, 1989.

12. Lazari-Pawłowska, I. Etyka. Pisma wybrana, Wrocław: Zakład Narodowy im. Ossolińskich, 1992.

13. Ładyga, Z., and J. Włodarczyk (eds.). Po humanizmie. Od technokrytyki do animal studies, Gdańsk: Wydawnictwo Naukowe Katedra, 2015.

14. MacIntyre, A. Krótka historia etyki. Filozofia moralności od czasów Homera do XX wieku, Warszawa: Wydawnictwo Naukowe PWN, 2013.

15. Marton, F. Phenomenography - Describing Conceptions of the World Around Us, Instructional Science 10, 1981, pp. 177-200. 
16. Obrycka, M. Etyczny intuicjonizm - dylematy etyki niezależnej. In S. Dąbrowski, M. Obrycka (eds.), Edukacja - Wartości - Kontrowersje, Gdańsk: Wydawnictwo Naukowe Katedra, 2017, pp. $15-49$.

17. Obrycka, M. Rola etyki niezależnej w procesie kształtowania tożsamości moralnej, Forum Oświatowe 28 (2), 2016, pp. 223-240.

18. Okoń, W. Nowy stownik pedagogiczny, Warszawa: Wydawnictwo Akademickie „Żak”, 2007.

19. Petrażycki, L. O nauce, prawie i moralności, Warszawa: Państwowe Wydawnictwo Naukowe, 1985.

20. Petrażycki, L. O pobudkach postępowania i o istocie moralności i prawa, Warszawa: Oficyna Naukowa, 2002.

21. Rahner, K., and H. Vorgrimler. Mały słownik teologiczny, Warszawa: Instytut Wydawniczy Pax, 1996.

22. Scheler, M. Der Formalismus in der Ethik und die materiale Wertethik, Hamburg: Felix Meiner Verlag, 2014.

23. Scheler, M. Resentyment a moralność, Warszawa: Fundacja Aletheia, 2008.

24. Schneewind, J. B. The Invention of Autonomy. A History of Modern Moral Philosophy, Cambridge: Cambridge University Press, 1998.

25. Środa, M. Etyka dla myślacych. Podręcznik dla szkót gimnazjalnych, Warszawa: Wydawnictwo Czarna Owca, 2016.

26. Wadowski, J. Intuicja odzyskiwana w teologii i w myśleniu religijnym. In J. Wadowski (ed.), Rewindykacja intuicji. Wybrane aspekty filozoficznej $i$ teologicznej interpretacji zagadnienia, Radom: Wydawnictwo Naukowe i Literackie ATENEUM, 2013, pp. 225-252.

\section{Notes}

1. It can be said that in our times it is a trait too rarely met among researchers. This fact is largely influenced by striving to achieve the specialization and concretization of knowledge.

2. It turns out useful to apply in this context the term collective consciousness, which is exploited on the ground of phenomenographic explorations. This issue is interpreted on this level as the culture of community, the set of evidences in perception and judgment of the reality, and also as the cognitive habits [15, pp. 177-200].

3. The crucial role is played on this level by the respect for tradition.

4. The author applies the term collective psyche.

5. Petrażycki differentiated among emotions (which were for him the fundament of the psychical life), sensations, feelings and will. Besides, the savant regarded examples of the awareness of the moral and legal duty as psychical phenomena.

6. At the turn of XX-XXI centuries, the term 'intuition' began to be interpreted in the meaning of the creative imagination and perception.

7. This is why we shouldn't reduce intentionality exclusively to that which is material and physical. The expression of this belief is the rejection by intuitionists of the views formulated on the ground of emotivism and naturalism.

8. We can't omit the fact, which isn't mentioned by Kotarbiński, that conscience prompts different things to different people. This risk is seen much broaderly by Petrażycki.

9. It's worth adding that Petrażycki described in his works the so-called standards of decency.

10. The conception of ethics without code, formulated by Leszek Kołakowski, was accorded the fundamental significance in the question of the impossibility of formulating the universal ethical code.

11. The fact that the disputes connected with the question of valuations may turn out undecidable has to be taken into account. 